\title{
O artigo científico
}

DIVA ROSA MALUCELLI DE OLIVEIRA (*)

A finalidade essencial de um artigo científico é comunicar idéias e informações de maneira clara, concisa e honesta (3). E necessário porém, existir uma normalização no registro da informação, atualmente uma das mais importantes áreas da Documentação.

Muito se tem feito, no mundo inteiro, no sentido de normalizar a enorme produção de documentos, resultado do crescente desenvolvimento técnico científico que caracteriza o século XX. Quanto mais uniforme fôr o registro da informação científica, mais fácil será o contrôle da produção bibliográfica, simplificando sobremaneira ao usuário, a abordagem da informação que lhe interessa.

Podemos citar a Unesco (3) e a ISO (International Organi. zation for Standardization) no plano internacional e a ABNT (Associação Brasileira de Normas Técnicas (1) no Brasil, como entidades que têm trabalhado no sentido de normalização do registro da informação.

Aqui será dada uma norma geral de apresentação de artigos científicos, não pretendendo ser ểste um trabalho exaustivo, mas sim prático. Estas normas são mais aplicáveis à trabalhos de pesquisa experimental portanto, no caso de outros tipos de trabalhos, tais como apresentação de casos clínicos, observações, estado atual de um assunto, estas poderão ser adaptadas, limitando-se ou expandindo-se as seç̧ões, procurando não fugir do esquema pré-determinado.

Estrutura do artigo científico

1. Preliminares 1.1. Título

1.2. Autor

1.3. Sinopse

2. Texto

2.1. Introdução

2.2. Material e métodos

2.3. Resultados ou observações

2.4. Discussão

2.5. Conclusões.

3. Referências 3.1. Resumo

3.2. Referências bibliográficas

3.3. Data e enderêço do autor.

* bibliotecária da Faculdade de Odontologia da Universidade Federal do Paraná.

$\begin{array}{lllll}\text { Dens Curitiba } & 1 & \text { (1): } & 7-9 & \text { out./dez. } 1971\end{array}$


1.1. Título - é um dos pontos mais importantes de um artigo científico, pois vai servir não só para atrair a atenção do leitor, como para facilitar a indexação do artigo em bibliografias especializadas no assunto. Evitar palavras supérfluas, e expressões como "uma contribuição para o estudo", "alguns aspectos", "considerações sôbre", "um estudo", "sôbre um caso de". Tais expressões são consideradas arcaicas e sem justificativa. Os títulos não devem ser muito genéricos, nem muito específicos. Escolher títulos claros, concisos, e que expressem da melhor maneira possível o conteúdo do trabalho. Caso o título sómente não sirva como especificativo do assunto, pode-se atribuir um subtítulo explicativo.

1.2. Autor - O nome do autor ou autores deve ser escrito for extenso. Indicações sôbre cargo ou função virão em nota de rodapé, na $1 .^{\mathrm{a}}$ página do artigo.

1.3. Sinopse - é a apresentação concisa (resumo) do texto do trabalho, devendo ser redigida pelo autor. A sinopse visa permitir ao leitor decidir sôbre a conveniência ou interêsse em ler o artigo. Ao redigir a sinopse, o autor deve ter $\mathrm{em}$ mente que esta pode ser a única parte do trabalho a ser lida, portanto deve ser suficientemente inteligível, constando de frases elíticas e não da simples enumeração de títulos das secções, capítulos ou partes. A sinopse será localizada logo depois do nome do autor, e antes do início do texto, datilografada em espaço 1 , em margem menor que a do texto própriamente dito. Usar no máximo 200 palavras. Há normas mais detalhadas para redação de sinopses, elaboradas pela $A B N T$.

2.1. INTRODUÇÃO - Nesta parte são delineadoś os obje_ tivos da pesquisa, deixando claros seus alcances e limitações, natureza do assunto, e, se o autor desejar, histórico e revista bibliográfica.

2.2. MATERIAL E METTODOS - É a descrição do material usado para a elaboração da pesquisa, e os métodos empregados para a sua consecução. Verbo no tempo passado.

Ex. "O material estudado constou de 23 arcadas dentárias humanas...."

2.3. RESULTADOS ou OBSERVAÇÕES - São os "achados", relatados friamente. Sómente o que foi observado, visto. Os resultados servem para introduzir as tabelas, ilustrações, fotografias. Não se fazem citações bibliográficas nesta parte. Verbo no tempo passado.

2.4. DISCUSSÃO - Nesta parte são feitos os comentários subjetivos. $\mathrm{O}$ autor dá as suas opiniões sôbre o assunto, seu ponto de vista, a partir do que foi observado. Pode comparar seus resultados e opiniões, com os de outros autores, sem porém deixar de citá-los bibliogràficamente. $O$ autor deve deixar claro o que é sua contribuição pessoal e o que não é (3).

$$
\begin{array}{lllll}
\text { Dens Curitiba } & 1 & \text { (1): } & 7-9 & \text { out./dez. } 1971
\end{array}
$$


Afirmações aceitas universalmente e não citadas nas referências bibliográficas, devem ser redigidas no tempo presente.

2.5. CONCLUSÕES - São as conclusões a que o autor chegou, a partir dos resultados e discussão. Evitar demasiado otimismo na afirmação da precisão do trabalho, ou na universalidade das conclusões (3). Se o autor preferir, pode omitir as conclusões e encaixá-las na discussão.

3.1. Resumo - E um resumo do texto do trabalho, em língua universalmente aceita, que não a do texto. Pode ou não ser feito pelo autor. Se em inglês, será chamado SUMMARY, em francês RESUMĒ, e em italiano RIASSUNTO. Usar no máximo 200 palavras.

3.2. Referências bibliográficas - devem ser elaboradas de acôrdo com as normas da Associação Brasileira de Normas Técnicas (PNB-66), e arranjadas alfabèticamente por autor. Aceitável na ordem de citação no texto. Numerá-las consecutivamente com algarismos arábicos.

3.3. Data e enderêço do autor - Dia, mês e ano em que o trabalho foi entregue para publicação, com vistas a evitar problemas de originalidade dos trabalhos. O enderêço visa permitir aos possíveis interessados no assunto, manterem correspondência com o autor.

\section{Referências bibliográficas}

1 ASSOCIAÇÃO BRASILEIRA DE NORMAS TECCNICAS. Normalização da documentação no ,Brasil. Rio de Janeiro, IBBD 1960. $104 \mathrm{p}$.

2 FERRAZ, T. A. "Tópicos bibliográficos". In: POURCHET CAMPOS, M. A. A docência e a investigação científica. São Paulo, 1962. p. 137-85.

3 UNESCO. Guia para a redação de artigos científicos destinados à publicação. Tradução de Lucy Gonçalves Fontes. Belo Horizonte Escola de Biblioteconomia da UFMG, 1969. 18 p.

Curitiba $8 / 10 / 71$. 